\title{
Changes in the quality characteristics and chemical compounds of garlic shoots for blanching
}

\author{
Hye-Jin Sim, Min-Jung Kang, Jung-Hye Shin* \\ Namhae Garlic Research Institute, Namhae 52430, Korea
}

\section{데치기 처리에 따른 마늘종의 이화학적 품질 특성 변화}

\author{
심혜진 · 강민정 · 신정혜* \\ (재) 남해마늘연구소
}

\begin{abstract}
This study was performed to investigate changes in the quality characteristics and chemical compounds in garlic shoots by blanching for different time $(0,0.5,1,2,3$, and $4 \mathrm{~min})$. The color ( $L$, a, and b values), texture profile (hardness, springiness, chewiness, gumminess, and cohesiveness), total vitamin $\mathrm{C}$, total sugar, total polyphenol and flavonoid, chlorophyll a and $b$ contents, total pyruvate and thiosulfinate contents of the blanched garlic shoots were examined. As the blanching time increased, the $L$ and $b$ values decreased, while the a value increased. Hardness, chewiness, springiness and gumminess of the blanched shoots were significantly lowered with the increasing blanching time. Vitamin $C$ content of raw garlic shoot was $1.62 \mathrm{mg} / 100 \mathrm{~g}$ while that of the blanched garlic shoots was 0.16 0.24 $\mathrm{mg} / 100 \mathrm{~g}$, implying vitamin $\mathrm{C}$ loss into blanching water and destruction by heat. The total sugar and polyphenol contents were fluctuated during blanching, but over $75 \%$ of their initial levels were retained under all blanching conditions. The total flavonoid contents increased as the blanching time increased. The chlorophyll a content did not show significant change with blanching time, but the chlorophyll b content significantly decreased. These results suggest that blanching for 2 min could be the best for retaining beneficial compounds and desirable quality of garlic shoot.
\end{abstract}

Key words : garlic shoots, blanching, quality characteristics

\section{서 론}

마늘은 추대 방식에 따라 완전추대, 불완전추대, 불추대 종으로 구분되는데(1), 우리나라에서 주로 재배되는 완전 추대종은 구근을 발육시키기 위해 5 월 초순경부터 마늘종 을 뽑아주거나 제거해야 하며 이 시기에 제거되지 않으면 구근의 성장이 이루어지지 않고 마늘종도 질겨져서 식용할 수 없게 된다(2). 마늘의 부산물인 마늘종은 마늘의 꽃줄기 로 마늘속대 또는 마늘 싹이라고 불리고 꽃대가 완전히

*Corresponding author. E-mail : whanbee@hanmail.net Phone : 82-55-860-8947, Fax : 82-55-860-8960

Received 23 December 2015; Revised 4 March 2016; Accepted 7 March 2016.

Copyright (c) The Korean Society of Food Preservation. All rights reserved.
자란 속 줄기이며(3) 마늘과 유사한 함황화합물을 지니고 있다. 또한 클로로필, 식이섬유, 비타민류 등의 함량이 마늘 에 비해 더 높아 마늘과 유사하면서도 차별화되는 성분들을 함유하고 있다(4,5). 이러한 유사한 성분들로 인해 마늘종 도 마늘과 같이 암이나 고혈압, 동맥경화, 심장질환, 뇌졸중 등의 질환 예방이나 치료에 효능이 있으며(6) 항산화, 항균 활성, 항혈전 및 항생 등의 활성이 있을 것으로 예상된다 $(7,8)$. 마늘종 추출물은 지질과산화물의 축적을 저해하고 $(9)$ 마늘종으로부터 분리된 플라보노이드 화합물들은 뛰어난 항산화 능력을 가지는 것이 입증되어 있다 $(2,10)$.

마늘 재배 농가에서는 부산물로 나오는 마늘종을 수확 초기에 판매하거나 일부는 저장하는데 마늘종이 단기간에 일시에 출하되며, 모든 과정이 수작업으로 이루어지고 있 어 노동력이 많이 요구되는 작업으로 일손이 부족하게 되면 그대로 폐기 처분되는 실정이다(11). 또한 마늘종은 마늘과 
유사한 매운맛과 향을 가지고 있어 생으로 섭취하기 힘들며 장기보관 시 저장성이 떨어지는 문제점이 있어(12) 안정적 인 원료수급의 어려움 등으로 인하여 산업적 활용이 용이하 지 않은 단점이 있다. 따라서 마늘종은 마늘과 유사한 특성 을 가진 신선채소로 인식되고 있음에도 불구하고, 가공식 품으로 개발되지 못하고, 장아찌와 같은 단순 가공품 또는 조리를 통해 부식으로 섭취되고 있는 실정이다.

채소는 신선상태 그대로 섭취하거나 가열조리한 후 섭취 하게 되는데, 가열 조리로 데치기, 찌기, 볶기, 튀기기, 굽기, 삶기 등의 다양한 방법이 있지만 가열하는 목적은 세포막을 유연하게 하여 소화가 잘 되게 하고, 각종 효소를 불활성화 시켜 영양소의 손실이나 갈변을 방지하기도 한다(13). 또한 약미성분을 용출하기도 하고 휘발성 물질을 방산하기도 하며 보존성을 높이는 등의 효과가 있고(14), 열처리 조리 과정을 거치면서 부피가 줄어들고, 조리를 통해 갖은 양념 을 첨가하여 보다 섭취를 용이하게 하며, 시금치의 수산처 럼 좋지 않은 성분을 제거하는데 도움을 준다(15).

다양한 열처리 방법 중 데치기는 조리 뿐만 아니라 채소 류의 가공에서 전처리 방법으로도 널리 사용되는데, 최근 에는 단체급식이나 외식업체를 중심으로 채소, 과일, 버섯 류 등을 데치기 처리하여 유통함으로써 인건비 절감, 조리 시간의 단축, 이용의 편의성을 증대시키는 방법으로 활용 되고 있다(16). 데치기 처리는 냉장저장 채소의 조직감을 안정적으로 유지시키고(17), 노화를 억제하고 저온장해를 완화시킬 뿐만 아니라 살균효과도 있다(18). 또 다른 측면에 서 제품의 연화, 색, 질감 및 향의 변화, 수용성 영양성분의 용출, 지용성 영양성분의 산화 등의 영향으로 품질의 열화 에도 영향을 미치게 되므로(19) 조리와 가공 모두에서 데치 는 조건은 품질과 상관성이 깊다.

지금까지 마늘종과 관련한 국내 연구는 재배 지역별 마 늘종의 이화학적 특성과 관련한 연구(20), 항산화성분과 항산화 활성에 관한 연구(2) 및 마늘종 추출물의 고지혈증 흰쥐의 지질개선에 미치는 영향(12)에 관한 연구가 수행되 어 있다. 그 외 마늘종의 항산화와 항균활성을 통해 냉장 패티에 적용하기 위한 연구(23)와 조리방법에 따른 마늘종 의 항산화 효능과 관련한 연구가 수행되어 있을 뿐 마늘종 의 관련한 연구는 아직 미진한 실정이다. 이에 본 연구에서 는 마늘종의 가공, 조리 특성과 관련한 기초자료를 확보하 고자 남해산 마늘종을 활용하여 데치기 시간에 따른 마늘종 의 주요성분과 품질특성 변화를 확인하고자 하였다.

\section{재료 및 방법}

\section{시료 제조}

마늘종은 경남 남해군에서 생산된 길이 $25 \sim 30 \mathrm{~cm}$, 직경 $0.5 \sim 0.7 \mathrm{~cm}$ 정도의 것을 신선한 상태로 구매하여 흐르는
물에 세척한 다음 자연 건조시켜 사용하였다. 마늘종을 약 $7 \mathrm{~cm}$ 길이로 잘라 무게 대비 10 배의 끓는 물에서 각각 30 초, 1 분, 2 분, 3 분 및 4 분 동안 데치기한 후 바로 냉수 중에서 식혀 흡수지 위에서 30 분간 자연건조 한 것을 시료로 사용 하였다.

\section{색도 측정}

마늘종을 곱게 마쇄하여 지름 $6 \mathrm{~cm}$ 의 petri dish에 담아 그 표면색을 색차계(Ultrascan VIS, Hunter Lab, VA, USA) 로 측정하였다. 이때 표준 백판의 $\mathrm{L}, \mathrm{a}$ 및 b 값은 각각 99.43 , $-0.1,0.06$ 이었다. 각 시료는 5 점 이상을 측정하여 평균값으 로 나타내었다.

\section{조직감 측정}

조직감은 texture analyzer(TAXT Plus, Stable Micro Systems, Surrey, UK)를 이용하여 측정하였다. 조건별로 데 치기 처리한 마늘종을 $5 \mathrm{~cm}$ 의 크기로 잘라 $\Phi 4 \mathrm{~mm}$ core를 이용하여 측정하였으며, 기기 조건으로 test speed는 5.0 $\mathrm{mm} / \mathrm{sec}$, post-test speed $3.0 \mathrm{~mm} / \mathrm{sec}$, time $3.0 \mathrm{~mm} / \mathrm{sec}$, distance $3.0 \mathrm{~mm}$ 로 TPA(two bite test, texture profile analysis) 테스트를 통하여 각 시료의 경도(hardness), 탄성(springiness), 씹힘성(chewiness), 점착성(gumminess) 및 응집성(cohesiveness) 을 측정하였다.

\section{총당 및 비타민 $\mathrm{C}$ 함량}

총당은 phenol- $\mathrm{H}_{2} \mathrm{SO}_{4}$ 법(22)에 따라 분쇄한 마늘종 $5 \mathrm{~g}$ 에 증류수를 가해 $50 \mathrm{~mL}$ 이 되도록 정용한 후 충분히 혼합하여 추출한 다음 여과한 시료액 $1 \mathrm{~mL}$ 에 $5 \%$ 페놀(Duksan, Ansan, Korea) 용액 $1 \mathrm{~mL}$ 및 진한 황산(Duksan, Ansan, Korea) $5 \mathrm{~mL}$ 을 가하고 30 분간 실온 정치시킨 후 분광광도 계(Libra S 35, Biochrom, Cambridge, England)를 이용하여 $470 \mathrm{~nm}$ 에서 흡광도를 측정하였으며, maltose(Sigma, St. Louis, MO, USA)로 표준검량곡선을 작성하고 총당 함량을 계산하였다.

비타민 C 함량은 HPLC(Ultimate 3000, Dionex, Sunnyvale, $\mathrm{CA}, \mathrm{USA}$ )로 분석하였다. 시료의 전처리는 $10 \mathrm{mg}$ 씩 100 $\mathrm{mL}$ 플라스크에 넣어 3차 증류수로 정용한 후, 용해시켜 표준용액을 만들었다. 이것을 3 차 증류수로 희석하여 적정 농도의 표준용액을 만들어 $0.45 \mu \mathrm{m}$ membrane filter로 여과 하여 사용하였다. Column은 Acclaim PA2, 내경 $3 \mu \mathrm{m}$, $4.6 \times 150 \mathrm{~mm}$ 을 사용하였으며, column 온도는 $35^{\circ} \mathrm{C}$, 이동상 은 $0.05 \%$ methanesulfonic acid(solvent A)와 acetonitrile (solvent B) 및 $10 \mathrm{mM} \mathrm{NH} \mathrm{H}_{2} \mathrm{PO}_{4}$ (solvent $\mathrm{C}$ )를 사용하여 gradient program에 따라 조절하였으며, 이동상의 유속은 $1 \mathrm{~mL} / \mathrm{min}$ 로 하였으며, 시료용액의 주입량은 $30 \mu \mathrm{L}$ 로 하 였다. 
총 폴리페놀 및 플라보노이드 화합물의 정량

데치기시간에 따른 마늘종의 총 폴리페놀 및 플라보노이 드 화합물의 함량을 측정하기 위하여 분쇄한 마늘종 $5 \mathrm{~g}$ 에 증류수로 $50 \mathrm{~mL}$ 이 되도록 한 후 여과한 액을 사용하였다. 총 폴리페놀 화합물의 함량은 Folin-Denis법(23)에 따라 시 료액 $1 \mathrm{~mL}$ 에 2M Folin-Ciocalteau 시약(Sigma Co., St. Louis, $\mathrm{MO}, \mathrm{USA}$ ) $1 \mathrm{~mL}$ 를 넣고 3 분 후 $10 \% \mathrm{Na}_{2} \mathrm{CO}_{3}$ (Daejung, Siheung, Korea) 용액 $1 \mathrm{~mL}$ 씩을 혼합하여 실온의 암실에서 1시간 정치한 다음 분광광도계(Libra S 35, Biochrom, Cambridge, England)를 이용하여 $760 \mathrm{~nm}$ 에서 흡광도를 측 정하였다. 표준물질로 gallic acid(Sigma Co., St. Louis, MO, USA)를 사용하여 시료와 동일한 방법으로 분석하여 얻은 검량선으로부터 총 폴리페놀 화합물의 함량을 계산하였다.

플라보노이드 함량은 시료액 $1 \mathrm{~mL}$ 에 $10 \%$ aluminum nitrate $0.1 \mathrm{~mL}, 1 \mathrm{M}$ potassium acetate $0.1 \mathrm{~mL}$ 및 $80 \%$ 에탄올 $4.3 \mathrm{~mL}$ 을 차례로 가하여 잘 혼합하고 상기와 동일한 방법으 로 반응시켜 $415 \mathrm{~nm}$ 에서 흡광도를 측정 하였다(24). Quercetin(Sigma Co., St. Louis, MO, USA)을 표준물질로 하여 얻은 검량선에 따라 플라보노이드 화합물의 함량을 계산하였다.

\section{클로로필 함량}

클로로필의 추출 및 정량은 Kozukue와 Friedman의 방법 (25)을 사용하여 시료 $5 \mathrm{~g}$ 에 $80 \%$ 아세톤을 가해 $50 \mathrm{~mL}$ 로 만들어 추출하고 여과한 여액을 시료로 하여 분광광도계 (Libra S35, Biochrome Ltd., Cambridge, England)로 $645 \mathrm{~nm}$ 와 $663 \mathrm{~nm}$ 에서 흡광도를 측정한 다음 아래의 계산식에 의해 산출하였다.

Chlorophyll a(mg/L) $=12.72 \times \mathrm{OD}_{663}-2.58 \times \mathrm{OD}_{645}$

Chlorophyll $\mathrm{b}(\mathrm{mg} / \mathrm{L})=22.88 \times \mathrm{OD}_{645}-5.50 \times \mathrm{OD}_{663}$

Total chlorophyll $(\mathrm{mg} / \mathrm{mL})=7.22 \times \mathrm{OD}_{663}+20.3 \times \mathrm{OD}_{645}$

\section{총 피루베이트 및 티오설피네이트 함량}

총피루베이트는 Schwimmer와 Weston(26)의 방법에 따 라 분쇄한 마늘종 $0.5 \mathrm{~g}$ 에 $10 \%$ trichloroacetic acid(TCA) 용액 $5 \mathrm{~mL}$ 를 넣고 균질화하여 1시간 정치한 후 여과지로 여과하였다. 여액 $1 \mathrm{~mL}$ 에 $0.0125 \%$ dinitriphenylhydrazine $1 \mathrm{~mL}$ 를 가하여 $37^{\circ} \mathrm{C}$ 에서 10 분간 반응시킨 다음 $0.6 \mathrm{~N}$ $\mathrm{NaOH}$ 용액 $5 \mathrm{~mL}$ 를 가하여 $420 \mathrm{~nm}$ 에서 흡광도를 측정하였 다.

티오설피네이트는 Freeman과 Mcbreen의 방법(27)에 따 라 분쇄한 마늘에 10 배량의 $10 \% \mathrm{TCA}$ 를 가하여 추출-여과 한 여액 $2 \mathrm{~mL}$ 에 2 배량의 hexane을 넣고 2 분간 진탕 추출한 다음 hexane층을 취하여 $254 \mathrm{~nm}$ 에서 흡광도를 측정하였다.

총피루베이트 및 티오설피네이트의 정량은 각각 sodium pyruvate(Sigma-Aldrich Co., St. Louis, MO, USA) 및
L-cystein (Sigma-Aldrich Co., St. Louis, MO, USA)을 표준 물질로 하여 작성한 검량선으로부터 산출하였다.

\section{통계처리}

모든 실험은 3회 이상 반복하여 실시하였으며 실험으로 부터 얻은 결과는 SPSS 12.0(SPSS Inc., Chicago, IL, USA) 을 사용하여 분석하였다. 결과치는 실험군당 평균 \pm 표준편 차로 표시하였고, 통계적 유의성 검정은 일원배치 분산분 석(one-way analysis of variance)을 한 후 $\mathrm{p}<0.05$ 수준에서 Duncan's multiple range test를 시행하였다.

\section{결과 및 고찰}

데치기 시간에 따른 색도 변화

데치기 시간 $(0,0.5,1,2,3,4$ 분 $)$ 에 따른 마늘종의 색도를 측정한 결과(Table 1$)$, 데치지 않은 마늘종의 $\mathrm{L}, \mathrm{a}$ 와 $\mathrm{b}$ 값은 각각 $45.21 \pm 1.22,-7.75 \pm 0.93,17.88 \pm 2.76$ 였다. 데치기 시간 이 길어질수록 마늘종의 색은 육안 상으로 녹색이 사라지며 어두워졌는데, 명도를 나타내는 L값은 감소하였으며, a값 은 점차 증가하는 경향을 보였다. 이는 녹색을 발현하는 엽록소의 녹색색상이 열에 의하여 분해되거나 색상이 여린 pheophytin 또는 pheophorbide 등으로의 전환, 또는 높은 온도에서 아미노산의 a-amino group과 당과의 반응에 의한 갈변반응 $(28,29)$ 이 일어났기 때문으로 생각된다. 그리고 황 색도를 나타내는 $\mathrm{b}$ 값은 $12.48 \pm 2.67 \sim 15.08 \pm 1.55$ 의 범위로 데치지 않은 마늘종에 비해 유의적으로 낮았다.

식품에 있어서 색은 맛, 향 및 영양성분과 함께 그 식품의 신선도, 성숙도, 품질 등을 판단하는 중요한 요소인데, 데침 처리 시간을 달리한 참취의 경우에도 데치는 시간이 증가할 수록 $\mathrm{L}$ 값은 감소하고 $\mathrm{a}$ 값은 증가하며 데치기 온도와 처리 시간의 영향을 많이 받는다고는 연구결과(19)는 본 연구의 결과와 동일한 경향이었다.

Table 1. Changes in Hunter's color value of garlic shoots treated by different blanching times

\begin{tabular}{ccccc}
\hline $\begin{array}{c}\text { Blanching time } \\
(\text { min })\end{array}$ & $\mathrm{L}$ & $\mathrm{a}$ & $\mathrm{b}$ & $\Delta \mathrm{E}$ \\
\hline 0 & $45.21 \pm 1.22^{1) \mathrm{c} 2)}$ & $-7.75 \pm 0.93^{\mathrm{b}}$ & $17.88 \pm 2.76^{\mathrm{c}}$ & $57.19 \pm 0.17^{\mathrm{ab}}$ \\
0.5 & $45.05 \pm 0.51^{\mathrm{c}}$ & $-9.67 \pm 0.44^{\mathrm{a}}$ & $15.08 \pm 1.55^{\mathrm{ab}}$ & $56.79 \pm 0.01^{\mathrm{a}}$ \\
1 & $44.19 \pm 1.14^{\mathrm{bc}}$ & $-9.14 \pm 0.88^{\mathrm{a}}$ & $15.72 \pm 1.55^{\mathrm{bc}}$ & $57.71 \pm 0.52^{\mathrm{ab}}$ \\
2 & $43.46 \pm 0.41^{\mathrm{ab}}$ & $-7.61 \pm 0.27^{\mathrm{b}}$ & $15.11 \pm 0.88^{\mathrm{ab}}$ & $58.00 \pm 0.64^{\mathrm{b}}$ \\
3 & $43.68 \pm 0.71^{\mathrm{ab}}$ & $-6.84 \pm 0.21^{\mathrm{b}}$ & $14.41 \pm 0.76^{\mathrm{bb}}$ & $57.51 \pm 0.46^{\mathrm{ab}}$ \\
4 & $42.67 \pm 1.22^{\mathrm{a}}$ & $-5.20 \pm 0.81^{\mathrm{c}}$ & $12.48 \pm 2.67^{\mathrm{a}}$ & $57.91 \pm 0.68^{\mathrm{b}}$ \\
\hline
\end{tabular}

${ }^{1)}$ All values are mean \pm SD $(\mathrm{n} \geqq 5)$.

${ }^{2) a-c}$ Means in same the column with different superscripts are significantly different by Duncans's multiple range test at $p<0.05$. 
데치기 시간에 따른 물성 변화

데친 마늘종의 물성변화를 측정한 결과는 Table 2 와 같 다. 경도는 제품 질감의 적합성을 보장하기 위해 필수적이 며 품질을 결정하는 가장 중요한 조건 중의 하나이다(19). 생마늘종의 경도는 $2431.19 \pm 95.44 \mathrm{~g}$ 였고, 데친 마늘종의
데치기 시간에 따른 마늘종의 총당 및 비타민 C 함량 변화

식품 중에 존재하는 당류는 화학적으로 환원성을 가지는 지에 따라 환원당과 비환원당으로 나눌 수 있는데, 이를 합하여 총당이라고 한다(32). 데치기 시간을 달리하여 마늘

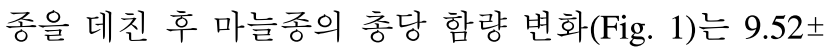

Table 2. Changes in texture characteristics of garlic shoots treated by different blanching times

\begin{tabular}{cccccc}
\hline $\begin{array}{c}\text { Blanching time } \\
(\mathrm{min})\end{array}$ & $\begin{array}{c}\text { Hardness } \\
(\mathrm{g})\end{array}$ & Springiness & Chewiness & Gumminess & Cohesiveness \\
\hline 0 & $2431.19 \pm 95.44^{1) 22}$ & $1.07 \pm 0.11^{\mathrm{c}}$ & $1025.19 \pm 111.31^{\mathrm{e}}$ & $920.16 \pm 106.26^{\mathrm{e}}$ & $0.37 \pm 0.04^{\mathrm{b}}$ \\
0.5 & $1810.81 \pm 72.03^{\mathrm{d}}$ & $0.92 \pm 0.12^{\mathrm{ab}}$ & $503.96 \pm 59.71^{\mathrm{d}}$ & $586.22 \pm 84.42^{\mathrm{d}}$ & $0.39 \pm 0.14^{\mathrm{b}}$ \\
1 & $1542.11 \pm 88.61^{\mathrm{c}}$ & $0.86 \pm 0.16^{\mathrm{a}}$ & $462.67 \pm 89.90^{\mathrm{c}}$ & $529.92 \pm 56.31^{\mathrm{cd}}$ & $0.34 \pm 0.20^{\mathrm{ab}}$ \\
2 & $1525.27 \pm 96.05^{\mathrm{c}}$ & $0.98 \pm 0.10^{\mathrm{bc}}$ & $501.53 \pm 76.77^{\mathrm{d}}$ & $535.90 \pm 81.45^{\mathrm{cd}}$ & $0.43 \pm 0.16^{\mathrm{b}}$ \\
3 & $1300.57 \pm 58.02^{\mathrm{b}}$ & $0.92 \pm 0.12^{\mathrm{ab}}$ & $328.00 \pm 59.12^{\mathrm{b}}$ & $357.23 \pm 54.07^{\mathrm{b}}$ & $0.34 \pm 0.10^{\mathrm{ab}}$ \\
4 & $1118.49 \pm 61.03^{\mathrm{a}}$ & $0.92 \pm 0.16^{\mathrm{ab}}$ & $218.17 \pm 31.31^{\mathrm{a}}$ & $278.54 \pm 35.67^{\mathrm{a}}$ & $0.23 \pm 0.04^{\mathrm{a}}$ \\
\hline
\end{tabular}

${ }^{1)}$ All values are mean \pm SD $(n \geqq 5)$.

${ }^{2) \text { ate }}$ Means in same the column with different superscripts are significantly different by Duncans's multiple range test at $p<0.05$.

경도는 생마늘종에 비해 유의적으로 낮았다. 데치기 마늘 종의 경도는 30 초간의 단시간 데치기 처리 후 1810.81 $\pm 72.03 \mathrm{~g}$ 의 범위로 생마늘종에 비해 $75 \%$ 정도로 급격하게 감소하였고 이후도 데치기 시간이 경과할수록 경도는 감소 하여 4분간 처리하였을 때는 $1118.49 \pm 61.03 \mathrm{~g}$ 로 생마늘종 의 경도에 비해 $46 \%$ 정도로 감소하였다. 탄력성은 데치기 처리 후 생마늘종에 비해 유의적으로 낮아졌으나 데치기 처리 시간에 따른 유의적인 차이는 없었다. 씹힘성은 데치 기 처리 후 생마늘종에 비해 약 $50 \%$ 감소하였고, 데치기 2 분까지는 처리시간에 따른 유의적인 차이가 없었다. 검성 도 씹힘성과 유사한 경향이었으며, 4분간 데치기 처리 후에 는 $278.54 \pm 35.67$ 로 생마늘종에 비해 약 $31 \%$ 수준이었다. 마늘종의 물성은 데치기 처리 유무에 영향을 크게 받으며, 단시간의 데치기 처리로도 경도는 크게 감소하지만 2 분까 지는 생마늘종 대비 $60 \%$ 이상의 경도를 유지하였다.

데치기 처리한 대파의 경우도 신선상태에 비해 32.26 $72.35 \%$ 까지 경도가 감소하는데 처리 온도가 높을수록, 시 간이 길수록 식물조직의 부피, 밀도, 중량 및 세포구조의 변화에 미치는 영향이 더 커서 조직의 경도가 감소하여 연화가 진행됨으로써 조직감에 영향을 미친다는 보고(30) 는 본 연구결과와도 일치하는 경향이었다. 데치기 처리 2 분 이내의 시료간에 물성에 큰 차이가 없었던 것은 도라지의 경우 생도라지에 비해 1,3 분 데침 처리 후 경도는 감소하였 으나 통계적인 유의차는 없어 5 분이내의 단시간 처리시는 데치기 처리가 조직감에 큰 영향을 미치지 않을 것이라는 Choi 등(31)의 보고로 미루어 볼 때 도라지나 마늘종처럼 시료 자체의 경도가 일반 엽채류 등에 비해 높은 경우 단기 간의 열처리에 의한 조직 연화의 이화학적 특성 변화가 상대적으로 낮기 때문으로 판단된다.

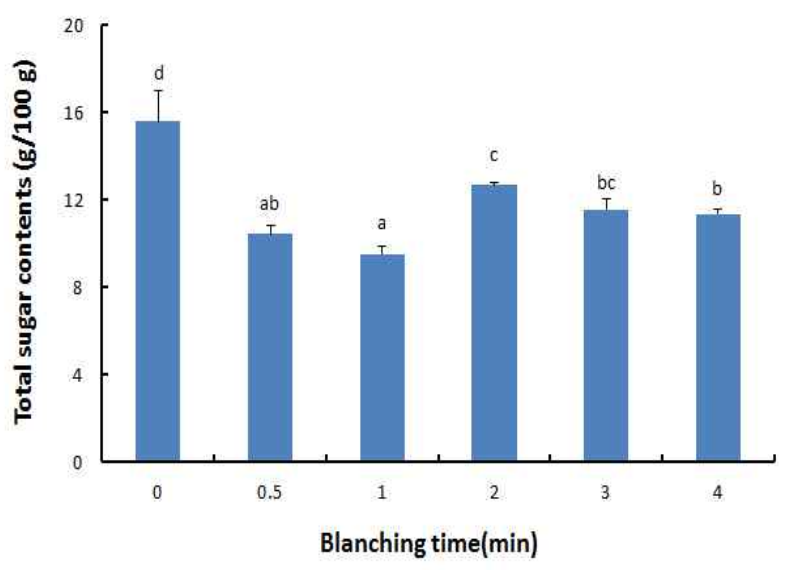

Fig. 1. Changes in total sugar contents of garlic shoots treated by different blanching times.

All values are mean \pm SD $(n \geqq 3)$.

${ }_{\text {add }}$ Means in same the column with different superscripts are significantly different by Duncans's multiple range test at $\mathrm{p}<0.05$.

$0.36 \sim 12.66 \pm 0.11 \mathrm{~g} / 100 \mathrm{~g}$ 의 범위로 데치지 않은 마늘종 $(15.56 \pm 1.39 \mathrm{~g} / 100 \mathrm{~g})$ 에 비해 유의적으로 낮았다.

Jeong 등(33)은 배암차즈기를 열풍 건조할 때 데치기 처 리한 경우 당의 총량이 더 감소하였는데, 이는 데치는 과정 중에 일부 당류가 조리 용수 중으로 빠져 나가거나 열에 의해 단당류로 분해되어 이당류는 감소하고 단당류는 증가 하였기 때문이라고 하였는데, 본 연구에서도 데치는 과정 중에 일부 당류가 데침 용수 중으로 빠져 나감으로써 총당 의 함량이 감소한 것으로 추정된다.

데치기 시간에 따른 마늘종의 비타민 $\mathrm{C}$ 함량 변화 결과는 Fig. 2와 같다. 마늘종 생시료의 비타민 C 함량은 $1.62 \pm 0.04$ $\mathrm{mg} / 100 \mathrm{~g}$ 이었고 30 초간 데쳤을 때에는 $0.24 \pm 0.02 \mathrm{mg} / 100$ 
$\mathrm{g}$ 으로 감소하여 약 $85 \%$ 가 소실되었다. 데치는 시간이 늘어 남에 따라 비타민 $\mathrm{C}$ 의 함량은 점차 감소하여 마늘종을 4 분 간 데쳤을 때의 비타민 $\mathrm{C}$ 의 잔존량은 약 $10 \%$ 인 $0.16 \pm 0.01$ $\mathrm{mg} / 100 \mathrm{~g}$ 에 불과하였다.

Chung과 $\operatorname{Kim}(34)$ 이 조리방법에 따른 마늘종의 변화를 관찰한 결과 생마늘종의 비타민 $\mathrm{C}$ 함량은 한지형과 난지형 이 각각 $48.4 \pm 0.9 \mathrm{mg} / 100 \mathrm{~g}$ 과 $51.8 \pm 0.7 \mathrm{mg} / 100 \mathrm{~g}$ 인데 반해 데치거나 볶음 처리 후에는 크게 감소하여 잔존율은 약 $10 \%$ 정도라고 보고한 바 있으며, 깻잎의 경우에는 30 초간 의 단시간 열처리시 비타민 $\mathrm{C}$ 는 $70 \%$ 이상의 잔존율을 나타 내었지만 5 분간의 열처리 잔존율은 $22 \%$ 정도라는 보고(35) 도 있는데 이들은 본 연구의 결과와도 동일한 경향이었다.

야채류를 주로 물에 담가 두거나 데친 후 양념하여 섭취 하는 전통적인 조리과정의 특성상 수용성인 비타민 $\mathrm{C}$ 의 손실은 불가피한데, 동일하게 데치기 하였을 때 원료에 따 라서 비타민 C의 손실량은 차이가 있어 참죽은 $434 \%$, 오가 피는 $29.72 \%$ 이며, 두릅은 생시료에 비해 $88.36 \%$ 가 손실되 어 다른 영양소에 비해 감소율이 매우 높은데, 이는 비타민 $\mathrm{C}$ 가 조리용수로 용출되거나 열에 의해 쉽게 파괴되기 때문 이라고 보고(36)되어 있다.

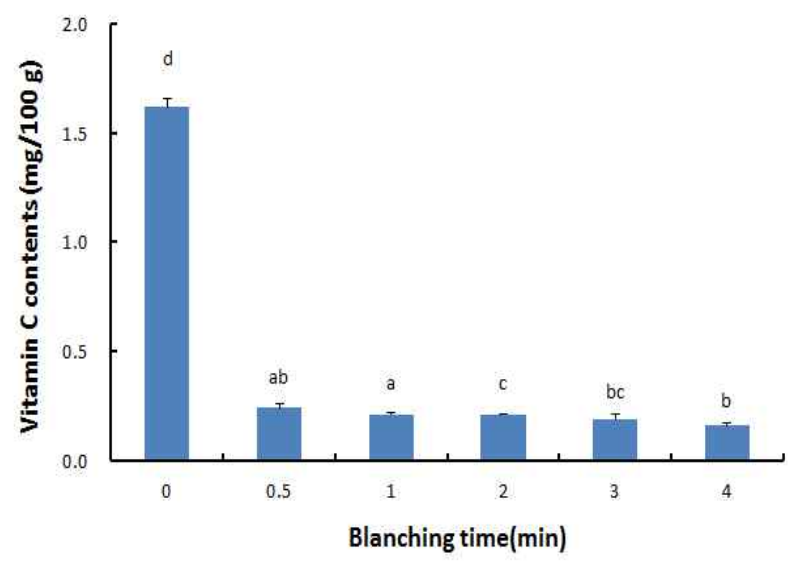

Fig. 2. Changes in vitanin $\mathrm{C}$ contents of garlic shoots treated by different blanching times.

\footnotetext{
All values are mean $\pm S D(n \geqq 3)$.

${ }^{a-d}$ Means in same the column with different superscripts are significantly different by Duncans's multiple range test at $\mathrm{p}<0.05$.
}

데침 시간에 따른 마늘종의 폴리페놀 및 플라보노이드 화 합물의 함량 변화

페놀성 화합물들은 식물체에 존재하는 2 차 대사산물의 하나로 라디칼에게 수소를 공여함으로써 라디칼을 제거하 여 산화를 억제하는데, 페놀성 화합물의 대부분은 $\mathrm{C}_{6}-\mathrm{C}_{3}-\mathrm{C}_{6}$ 구조의 플라보노이드 화합물이며 항산화 및 항균성을 갖는 것으로 보고되어 있다(37).

데치기 시간에 따른 마늘종의 폴리페놀 및 플라보노이드 화합물의 함량을 분석한 결과는 각각 Fig. 3 및 4 와 같다.
생마늘종의 폴리페놀 및 플라보노이드 화합물의 함량은 각각 $47.49 \pm 0.89 \mathrm{mg} / 100 \mathrm{~g}$ 과 $21.51 \pm 2.41 \mathrm{mg} / 100 \mathrm{~g}$ 이었다. 데친 마늘종의 경우 생 마늘종에 비해 폴리페놀 화합물의 함량은 감소하는 반면 플라보노이드의 함량은 증가하는 경향이었으며, 데치기 시간에 따라 그 함량의 변화양상도 서로 상이하였다. 즉, 총 페놀화합물의 경우 0.5 분간 데침 처리하였을 때 $35.92 \pm 1.93 \mathrm{mg} / 100 \mathrm{~g}$ 으로 생마늘종에 비해 $76 \%$ 정도로 감소하였던 것이 2 분간 데치기 처리 시는 $44.27 \pm 4.01 \mathrm{mg} / 100 \mathrm{~g}$ 으로 최고 함량이었다가 그 이후부터 다시 감소하였다. 플라보노이드의 함량은 데침 처리 2 분까 지는 그 함량이 증가하여 $48.29 \pm 1.31 \mathrm{mg} / 100 \mathrm{~g}$ 이었고, 그 이후 다시 감소하였다.

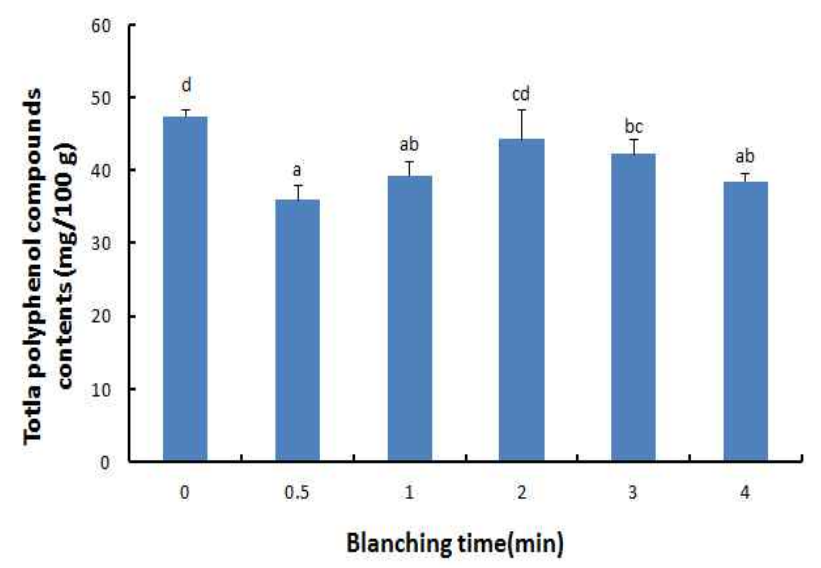

Fig. 3. Changes in total polyphenol compounds contents of garlic shoots treated by different blanching times.

All values are mean $\pm S D(n \geqq 3)$.

${ }^{\text {ae }}$ Means in same the column with different superscripts are significantly different by Duncans's multiple range test at $p<0.05$.

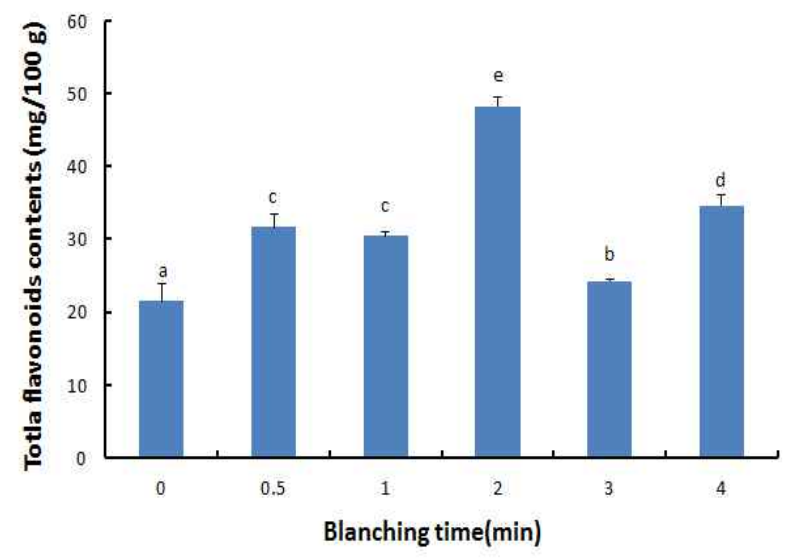

Fig. 4. Changes in flavonoids contents of garlic shoots treated by different blanching times.

All values are mean $\pm S D(n \geqq 3)$.

${ }^{\text {ae }}$ Means in same the column with different superscripts are significantly different by Duncans's multiple range test at $p<0.05$. 
마늘종을 1 분간 데치기 처리하였을 때 생마늘종에 비해 그 함량이 감소하였다는 보고(34)와 1 분 간격으로 5 분간 데침 처리한 참취의 총 폴리페놀 화합물의 함량은 데침 처리 4 분에 가장 높고, 5 분간 데침 처리하였을 때 가장 낮은 함량이었다고는 보고(19)는 본 연구의 결과와 유사한 경향 이었다. 총 폴리페놀 화합물의 함량은 데칠 때 산화로 인한 열분해와 항산화제의 손실 및 물속으로의 침출에 의해 그 함량이 감소하는 것으로 판단되고 있다(38).

반면 데치기 처리한 참나물의 총 폴리페놀과 플라보노이 드 함량은 생시료에 비해 각각 3.7 배와 4.0 배 정도 더 증가하 였는데, 이는 다른 조리법에 비해 더 높은 함량이라는 보고 (39)가 있는가 하면, 데치기 한 시래기의 플라보노이드 함량 은 데치기 전에 비해 $4 \%$ 정도만 잔존하였다는 보고(40)도 있어 채소류의 가공 및 조리 중의 페놀이나 플라보노이드 함량은 원료 식물류의 조직적 특성이 서로 상이하여 데치는 동안 온도나 물의 양, 시간 등 열처리에 의한 영향이 다르기 때문에 데친 후의 함량변화 양상도 차이를 나타내는 것으로 추정된다.

\section{데치기 시간에 따른 클로로필 함량의 변화}

식물에 널리 분포되어 있는 천연 녹색 색소인 클로로필 은 카로티노이드, 지질 및 지방단백질 등과 결합된 상태로 존재하는데, 광선이 차단된 상태에서 결합력이 약해지면 유리라디칼 소거제로 작용하여 지방질의 자동산화를 방지 하는 생리작용을 가지는 등 여러 생리활성을 나타내어 건강 보조 식품으로 널리 이용되고 있으며 $(41,42)$, 채소나 과일 의 신선함을 나타내는 지표가 되기도 한다(43).

$95^{\circ} \mathrm{C}$ 이상의 끓는 물에서 데치기 시간을 다르게 한 마늘 종의 클로로필 함량 변화를 분석한 결과는 Table 3 과 같이 총 클로로필의 함량은 79.49 $\pm 2.46 ~ 106.97 \pm 9.69 \mu \mathrm{g} / \mathrm{g}$ 이었 고, 데침 시간이 길어질수록 점차 감소하는 경향이었다. 생마늘종의 총 클로로필 함량은 $103.92 \pm 1.16 \mu \mathrm{g} / \mathrm{g}$ 이었는데, 30 초 데친 마늘종에서는 $106.97 \pm 9.69 \mu \mathrm{g} / \mathrm{g}$ 으로 총 클로로필

Table 3. Chlorophyll contents of garlic shoots for blanching conditions

$(\mu \mathrm{g} / \mathrm{g})$

\begin{tabular}{cccc}
\hline $\begin{array}{c}\text { Blanching time } \\
(\mathrm{min})\end{array}$ & Chlorophyll-a & Chlorophyll-b & Total chlorophyll \\
\hline 0 & $74.76 \pm 0.83^{\text {cd }}$ & $29.16 \pm 1.99^{\mathrm{c}}$ & $103.92 \pm 1.16^{\mathrm{d}}$ \\
0.5 & $79.82 \pm 8.91^{\mathrm{d}}$ & $27.15 \pm 3.95^{\mathrm{c}}$ & $106.97 \pm 9.69^{\mathrm{d}}$ \\
1 & $73.94 \pm 4.30^{\mathrm{bcd}}$ & $20.26 \pm 1.74^{\mathrm{b}}$ & $94.21 \pm 5.07^{\mathrm{c}}$ \\
2 & $71.36 \pm 1.46^{\mathrm{abc}}$ & $20.88 \pm 2.86^{\mathrm{b}}$ & $92.25 \pm 1.45^{\mathrm{bc}}$ \\
3 & $66.15 \pm 1.82^{\mathrm{ab}}$ & $18.11 \pm 1.20^{\mathrm{ab}}$ & $84.26 \pm 1.59^{\mathrm{ab}}$ \\
4 & $64.00 \pm 1.40^{\mathrm{a}}$ & $15.50 \pm 1.06^{\mathrm{a}}$ & $79.49 \pm 2.46^{\mathrm{a}}$ \\
\hline
\end{tabular}

All values are mean \pm SD ( $n \geqq 3)$

${ }^{a-d}$ Means in same the column with different superscripts are significantly different by Duncans's multiple range test at $\mathrm{p}<0.05$.
함량이 미량 증가하였는데, 이는 클로로필라제와 같이 고 온에서 활성이 있는 효소가 부활하여 클로로필을 클로로필 린으로 변화시키거나(44) 열에 의해 단백질과 약간 결합 상태로 있던 클로로필이 유리되어(45) 일시적으로 그 함량 이 증가되었기 때문으로 생각된다.

클로로필 $\mathrm{a}$ 는 녹색 식물 클로로필의 $75 \%$ 를 차지하는 가장 보편적이고 주요한 클로로필(46)로 알려져 있는데, 본 연구의 결과에서도 마늘종에서 청록색을 나타내는 클로 로필 $\mathrm{a}$ 가 황녹색을 나타내는 클로로필 $\mathrm{b}$ 에 비해 약 2.6 4.1 배 더 많이 함유되어 있고 데치는 시간이 길수록 그 감소량 이 더 큰 것을 확인할 수 있었다. 조리방법에 따른 열처리 조건에 따라 클로로필의 함량차이가 생기므로 클로로필이 고유의 색을 유지할 수 있도록 가공조건을 설정할 필요가 있다고 생각된다.

데치기 시간에 따른 총 피루베이트 및 티오설피네이트 함 량의 변화

티오설피네이트는 마늘에 함유되어 있는 분자 내에 황을 함유하고 있는 물질들을 통합하여 지칭하며, diallyl disulfide, diallyl trisulfide 및 diallyl sulfide 등이 티오설피네이트의 대부분을 차지한다. 이들 화합물은 마늘의 주요 생리활성 물질로 알려져 있으며, 대표적으로 항산화활성에 관여하는 것으로 알려져 있다(47). 마늘 중 총 피루베이트 및 티오설 피네이트는 마늘의 파쇄 시 생성되는 물질로 allicin의 함량 과 비례적인 것으로 보고되어 있으며, 숙성하거나 열처리 한 마늘의 총 피루베이트 및 티오설피네이트의 함량은 생마 늘에 비해 증가하였다(48).

데치기 시간에 따른 마늘종의 총 피루베이트 및 티오설 피네이트 함량을 측정한 결과는 Table 4와 같다. 데치지 않은 생마늘종의 총 피루베이트 및 티오설피네이트 함량은 각각 $49.46 \pm 0.59,11.48 \pm 0.33 \mu \mathrm{M} / \mathrm{g}$ 으로 데치는 과정을 거치 는 동안 약 $50 \%$ 수준으로 감소하여 데친 마늘종의 총 피루 베이트 및 티오설피네이트 함량은 21.83 $\pm 1.65 ~ 26.37 \pm 1.09$ $\mu \mathrm{M} / \mathrm{g}$ 과 $5.18 \pm 0.20 \sim 5.93 \pm 0.07 \mu \mathrm{M} / \mathrm{g}$ 이었다.

Table 4. Total pyruvate and thiosulfinate contents of garlic shoots for blanching conditions

$(\mu \mathrm{M} / \mathrm{g})$

\begin{tabular}{ccc}
\hline $\begin{array}{c}\text { Blanching time } \\
(\text { min) }\end{array}$ & Total pyruvate content & Total thiosulfinate content \\
\hline 0 & $49.46 \pm 0.59^{\mathrm{d}}$ & $11.48 \pm 0.33^{\mathrm{c}}$ \\
0.5 & $25.37 \pm 1.16^{\mathrm{bc}}$ & $5.93 \pm 0.07^{\mathrm{b}}$ \\
1 & $23.40 \pm 0.87^{\mathrm{ab}}$ & $5.18 \pm 0.20^{\mathrm{a}}$ \\
2 & $26.37 \pm 1.09^{\mathrm{c}}$ & $5.88 \pm 0.04^{\mathrm{b}}$ \\
3 & $21.83 \pm 1.65^{\mathrm{a}}$ & $5.44 \pm 0.06^{\mathrm{a}}$ \\
4 & $23.75 \pm 1.18^{\mathrm{ab}}$ & $5.23 \pm 0.07^{\mathrm{a}}$ \\
\hline
\end{tabular}

All values are mean $\pm S D(n \geqq 3)$.

${ }_{\text {a-d }}$ Means in same the column with different superscripts are significantly different by Duncans's multiple range test at $p<0.05$. 


\section{요 약}

마늘종의 가공, 조리 특성과 관련한 기초자료를 확보하 고자 데치기 시간(30초, 1 분, 2 분, 3 분, 4 분)을 달리한 남해산 마늘종의 색도, 물성, 총당, 비타민 $\mathrm{C}$, 클로로필, 총 폴리페 놀, 플라보노이드, 총 피루베이트 및 티오설피네이트 함량 을 분석하였다. 데치기 시간이 길어질수록 마늘종의 색은 $\mathrm{L}$ 값은 감소하였으며, $\mathrm{a}$ 값은 점차 증가하는 경향을 보였다. 그리고 황색도를 나타내는 $\mathrm{b}$ 값은 $12.48 \pm 2.67 \sim 15.08 \pm 1.55$ 의 범위로 데치지 않은 마늘종에 비해 유의적으로 낮았다. 생 마늘종의 경도는 $2431.19 \pm 95.44 \mathrm{~g}$ 이었는데, 데치기 시간의 증가와 더불어 감소하였다. 데침 시간을 달리한 마늘종의 총당과 비타민 $\mathrm{C}$ 의 함량은 데치지 않은 마늘종에 비해 유의 적으로 낮았고 데치기 시간에 따라 점차 감소하였는데 이는 조리용수로 용출되거나 열에 의해 파괴되었다고 생각된다. 총 클로로필의 함량은 79.49 $\pm 2.46 ~ 106.97 \pm 9.69 \mu \mathrm{g} / \mathrm{g}$ 이었으 며, 청록색을 나타내는 클로로필 a가 황녹색을 나타내는 클로로필 $\mathrm{b}$ 에 비해 약 2.6 4.1배 더 많이 함유되어 있고 데침 시간이 길어질수록 점차 총량이 감소하였다. 총 피루 베이트 및 티오설피네이트 함량은 데치는 과정을 거치는 동안 약 $50 \%$ 수준으로 감소하였다. 마늘종은 데치기 처리 시간에 따라 색도, 물성 및 주요 성분이 감소되므로 2 분 정도로 데침 처리 하는 것이 마늘종 고유의 성분과 품질을 유지하는데 적합한 것으로 판단된다.

\section{References}

1. Etoh T (1985) Studies on the sterility in garlic, Allum sativum L. Mem Fac Agr Kagoshima Univ, 21, 77-132

2. Chung JY, Kim CS (2008) Antioxidant activities of domestic garlic (Allium sativum L.) stems from different areas. J Korean Soc Food Sci Nutr, 37, 972-978

3. Kang MJ, Yoon HS, Shin JH (2012) Chemical properties and biological activity of garlic (Allium sativum L.) shoots. J Agric Life Sci, 46, 129-139

4. Kim MY, Choi SW, Chung SK (2000) Antioxidative flavonoids from the garlic (Allium sativum L.) shoot. Food Sci Biotechnol, 9, 199-203

5. Kim MY, Chung SK (1997) Analysis of nutritional and volatile flavor compounds of garlic shoot. Korean J Food Preserv, 4, 61-68

6. Kim YJ (2010) Effects of dietary supplementation of garlic by-products on total phenol contents, DPPH radical scavenging activity, and physicochemical properties of chicken meat. Korean J Food Sci Ani Resour, 30, 860-866

7. Jung KA, Park CS (2013) Antioxidative and antimicrobial activities of juice from garlic, ginger and onion. Korean J Food Preserv, 20, 134-139

8. Jeon SY, Baek JH, Jeong EJ, Cha YJ (2012) Volatile flavor compounds in commercial black garlic extracts. J Korean Soc Food Sci Nutr, 41, 116-122

9. Kim JB, Cho KJ, Hwang KA, Hwang YJ, Om AS, Kim IH (2011) Antiobesity and hypolipidemic effects of garlic (Allium sativum L.) stem extract in high fat diet-induced obese mice. 2011 Autumn symposium of Korean soc Med Crop Sci, Korea, 246-247

10. Fanelli SL, Castro GD, Toranzo EG, Castro JA (1998) Mechanism of the preventive properties of some garlic components in the carbon tetrachloride promoted oxidative stress. Diallyl sulfide, diallyl disulfide, allyl mercaptan and allyl methyl sulfide. Res Commun Mol Pathol Pharmacol, 102, 163-174

11. So JD, Kim GH, Kwon SH (2005) Mechanical characteristics of garlic scapes for developing mechanical garlic bulbils harvester. J of Biosystems Eng, 30, 75-80

12. Hwang CR, Kang JR, Kang MJ, Sim HJ, Shin JH (2015) Effect of garlic shoot extract on lipid metabolism in hyperlipidemic rats fed a high-fat diet. J Life Sci, 25, 276-284

13. Lee YC, Lee KH (1988) Effects of blanching, chemical dipping, freezing methods and storage period on quality of frozen mushrooms. Korean J Food Sci Technol, 20, 536-540

14. Lee K, Kim KH, Kim HK (2002) Thermal inactivation parameters of peroxidase in Flammulina velutipes and Lyophyllum ulmarium. Korean J Food Sci Technol, 34, 1067-1072

15. Park CH, Kim KH, Tae MH, Kim NY, Yook HS (2014) Cooking process for spinach and their effects on antioxidant and antimicrobial activities. Korean J Food Nutr, 27, 147-155

16. Jin HB, Choi EO (2001) Survey on the use of preprocessed foods in elementary school food services in Incheon. J Korean Soc Food Cult, 16, 250-259

17. Kim YH, Lee DS, Kim JC (2004) Effect of blanching on textural properties of refrigerated and reheated vegetables. J Korean Soc Food Sci Nutr, 33, 911-916

18. Lee JJ, Jung HO (2012) Changes in physicochemical properties of Spergularia marina Griseb by blanching. Korean J Food Preserv, 19, 866-872

19. Beom SW, Jiang GH, Eun JB (2015) Effect of blanching time on physicochemical characteristics and sensory evaluation of Aster scaber. Korean J Food Preserv, 22, 
$51-55$

20. Yoon HS, Kang MJ, Hwang CR, Sim HJ, Kim GM, Shin JH (2014) Physicochemical characteristics of garlic (Allium sativum L.) shoots from different areas in Namhae. Korean J Food Preserv, 21, 321-327

21. Min DR, Park SY, Chin KB (2010) Evaluation of antioxidantive and antimicrobial activities of garlic stem and red cabbage, and their application to pork patties during refrigerated storage. Korean J Food Sci Ani Resour, 30, 291-297

22. Dubois M, Gills KA, Hamilton JK, Rebers PA, Smith F (1956) Colorimetric method for determination of sugar and related substances. Anal Chem, 28, 350-356

23. Ragazzi E, Veronese G (1973) Quantitative analysis of phenol compounds after thin-layer chromatographic separation. J Chromatogr, 77, 369-375

24. Moreno MIN, Isla MIN, Sampietro AR, Vattuone MA (2000) Comparison of the free radical scavenging activity of propolis from several region of Argentina. J Ethnopharmacol, 71, 109-114

25. Kozukue N, Friedman M (2003) Tomatine, chlorophyll, $\beta$-carotene and lycopene content in tomatoes during growth maturation. J Sci Food Agric, 83, 195-200

26. Schwimmer S, Weston WJ (1961) Onion flavor and odor, enzymatic development of pyruvic acid in onion as a measure of pungency. J Agri Food Chem, 9, 301-304

27. Freeman GG, Mcbreen F (1973) A rapid spectrophotometric methods of determination of thiosulfinate in onion and its significance in flavor studies. Biochem Soc Trans, 1, 1150-1154

28. Jeon MR, Kim MH, Kim MY, Kim MR (2009) The effect of heat treatments and herb addition on flavor of garlic. J Korean Soc Food Sci Nutr, 38, 105-110

29. Park IK, Kim SD (2005) Effect of blanching on the quality characteristics of Dandelion (Taraxacum platycarpum D.) kimchi. J East Asian Soc Dietary Life, 15, 194-199

30. Lee HO, Lee YJ, Kim JY, Yoon DH, Kim BS (2011) Quality characteristics of frozen welsh onion (Allium fistulosum L.) according to various blanching treatment conditions. Korean J Food Sci Technol, 43, 426-431

31. Choi SY, Lee SY, Davaatseren M, Yoo SM, Choi MJ, Han HM (2014) Effect of blanching conditions and thawing methods on quality properties of platycodon grandiflorum Culinary Science and Hospitality Research, 20, 211-222

32. Kim JY, Sung KW, Bae HW, Yi YH (2007) pH, acidity, color, reducing sugar, total sugar, alcohol and organoleptic characteristics of puffed rice powder added Takju during fermentation. Korean J Food Sci Technol, 39, 266-271

33. Jeong JS, Kim YJ, Choi BR, Go GB, Son BG, Gang SW, Moon SM (2014) Antioxidant and physicochemical changes in Salvia plebeia R. Br. after hot-air drying and blanching. J Korean Soc Food Sci Nutr, 43, 893-900

34. Chung JY, Kim CS (2009) Antioxidant activities of domestic garlic (Allium sativum L.) stems and garlic bulbs according to cooking methods. J Korean Soc Food Sci Nutr, 38, 188-194

35. Choi YH (2003) Changes in vitamin C and minerals content of perilla leaves by different cooking methods. Korean J Food Cook Sci, 19, 174-180

36. Kim MH, Jang HL, Yoon KY (2012) Changes in physicochemical properties of Haetsun vegetables by blanching. J Korean Soc Food Sci Nutr, 41, 647-654

37. Ahn SI, Heuing BJ, Son JY (2007) Antioxidative activities and nitrite-scavenging abilities of some phenolic compounds. Korean J Food Cookery Sci, 23, 19-24

38. Lutz M, Henriquez C, Escobar M (2011) Chemical composition and antioxidant properties of mature and baby artichokes (Cynara scolymus L.), raw and cooked. J Food Comp Anal, 24, 49-54

39. Chae HS, Lee SH, Jeong HS, Kim WJ (2013) Antioxidant activity and physicochemical characteristics of Pimpinella brachycarpa Nakai with treatments methods. Korean J Food Nutr, 26, 125-131

40. Park CH, Kim KH, Yook HS (2014) Comparison of antioxidant and antimicrobial activities in Siraegi (dried radish greens) according to cooking process. Korean $\mathbf{J}$ Food Nutr, 27, 609-618

41. Yoon HS, Kang MJ, Hwang CR, Sim HJ, Kim GM, Shin JH (2014) Physicochemical characteristics of garlic (Allium sativum L.) shoots from different areas in Namhae. Korean J Food Preserv, 21, 321-327

42. Kwak YJ, Kim JS (2009) Changes of chlorophyll and SOD-like activities of Chinese chives dehydrated at different heat treatments. J Korean Soc Food Sci Nutr, 38, 879-884

43. Ryu SH, Lee HS, Lee YS, Kwon TW, Song YS, Moon GS (2005) Effect of $\beta$-carotene and vitamin $C$ on chlorophyll-induced photooxidation. J Korean Soc Food Sci Nutr, 34, 99-106

44. Han JS, Park KS, Heo SM, Song JE (2013) Experimental 
Cookery. Hyungseul Publishing Networks, Korea

45. Teng SS, Chen BH (1999) Formation of pyrochlorophylls and their derivatives in spinach leaves during heating. Food Chem, 65, 367-373

46. Tanielian C, Wolff C (1988) Mechanism of physical quenching of singlet molecular oxygen by chlorophylls and related compounds of biological interest. Photochem Photobiol, 48, 277-280
47. Kwon SK (2003) Organosulfur compounds from Allium sativum and physiological activities. J Appl pharmacol, 11, 8-32

48. Shin JH, Choi DJ, Lee SJ, Cha JY, Kim JG, Sung NJ (2008) Changes of physicochemical components and antioxidant activity of garlic during its processing. J Life Sci, 18, 1123-1131 